\title{
Obturacyjny bezdech senny (OBS) w powiązaniu z terapią ortodontyczną - przegląd polskiego piśmiennictwa
}

\author{
Obstructive Sleep Apnea (OSA) connection with orthodontic therapy - \\ a review of Polish literature \\ ${ }^{1}$ Poradnia Ortopedii Szczękowej i Ortodoncji, \\ Uniwersyteckiego Centrum Stomatologii i Medycyny Specjalistycznej, Spółka z o.o. \\ Clinic of Maxillofacial Orthopaedics and Orthodontics, \\ University Center of Dentistry and Specialized Medicine, Spółka z o.o.
}

${ }^{2}$ Katedra i Klinika Ortopedii Szczękowej i Ortodoncji, Uniwersytet Medyczny im. Karola Marcinkowskiego w Poznaniu Chair and Department of Maxillofacial Orthopaedics and Orthodontics, Poznan University of Medical Sciences

DOI: http://dx.doi.org/10.20883/df.2020.17

\section{STRESZCZENIE}

Obturacyjny bezdech senny (OBS) często wiąże się z problemami ortodontycznymi, laryngologicznymi i ogólnoustrojowymi. Ma szczególny wpływ na rozwój części twarzowej czaszki u dzieci oraz na ich rozwój psychoruchowy. U ludzi starszych może znacznie utrudniać codzienne funkcjonowanie oraz prowadzić do groźnych powikłań i chorób.

Cel. Celem pracy jest przedstawienie problemu obturacyjnego bezdechu sennego ujętego w polskim piśmiennictwie.

Materiał i metody. Przeanalizowano 30 artykułów z ostatnich szesnastu lat dotyczących tematyki obturacyjnego bezdechu sennego. Do przeglądu piśmiennictwa włączono 4 prace z ostatniego pięciolecia.

Wyniki. Autorzy analizowanych doniesień wykazali silny związek występowania OBS z chorobami ogólnoustrojowymi oraz z wadami części twarzowej czaszki. Diagnostykę zaburzeń górnych dróg oddechowych przeprowadzono na podstawie tomografii komputerowej i zdjęć cefalometrycznych.

Wnioski. Zespół obturacyjnego bezdechu sennego wymaga interdyscyplinarnego podejścia. Lekarz ortodonta może wesprzeć wstępną diagnostykę oraz skierować pacjenta na odpowiednie leczenie - laryngologiczne lub chirurgiczne.

Słowa kluczowe: obturacyjny bezdech senny - OBS, cefalometria, wady zębowo-zgryzowe, obrazowanie radiologiczne.

\section{ABSTRACT}

Obstructive sleep apnea is often connected with systemic, laryngological and orthodontic problems. It has a significant impact on craniofacial development in children and on their psychosomatic development. In elderly people it may impede everyday functioning and lead to serious diseases and complications.

Aim. The aim of the article is the obstructive sleep apnea OSA described in the polish literature.

Material and methods. 30 articles from the last 16 years connected with obstructive sleep apnea were analyzed. Four papers from the last five years were included into literature review.

Results. The authors of analyzed reports showed a strong relationship of OSA occurrence with systemic diseases and defects of the face skeleton. The diagnosis of disorders was carried out basing on cephalometric $x$-rays and computed tomography.

Conclusions. Obstructive sleep apnea requires interdisciplinary approach. The orthodontist can support the initial diagnosis and refer the patient to appropriate treatment - ENT (ear, nose, throat) or surgical.

Keywords: obstructive sleep apnea - OSA, cephalometry, malocclusions, radiological image. 


\section{Wstęp}

Obturacyjny bezdech senny - OBS charakteryzuje się kilkukrotnymi okresami częściowego (hypopnea) lub całkowitego (apnea) braku przepływu powietrza przez drogi oddechowe w ciągu nocy. Postać ciężka OBS charakteryzuje się występowaniem 30 epizodów bezdechu, średnia 15-30, a łagodna 5 do 10 na godzinę. W każdej z wymienionych postaci utrzymuje się senność dzienna, a w postaci ciężkiej może wystąpić w sytuacjach wymagających dużego skupienia uwagi, na przykład w trakcie prowadzenia pojazdu. Podczas snu obniża się tonus mięśniowy, także mięśni gardła w środkowej jego części pozbawionej rusztowania kostno-chrzęstnego. Niedobór tlenu we krwi oraz podwyższenie stężenia dwutlenku węgla wraz ze wzrostem wysiłku oddechowego prowadzi do gwałtownych wybudzeń [1-6]. Stopień zaawansowania choroby mierzy się wskaźnikiem AHI (apnea/ hypopnea index). Wskaźnik AHI u dzieci powyżej 5 wymaga leczenia specjalistycznego, podczas gdy u dorosłych z AHI poniżej 15, bez towarzyszących objawów klinicznych utrudniających codzienne funkcjonowanie, nie jest wskazaniem do podjęcia leczenia [2, 4]. Diagnostyka OBS opiera się na wywiadzie z pacjentem, następnie na badaniu polisomnograficznym uzupełnionym o zapis EKG, pomiarze tętna, wysyceniu krwi tlenem [7]. Skutki nieleczonego OBS to między innymi opóźnienie rozwoju dzieci i nawracające infekcje. Autorzy w przypadku zaawansowanych wad wrodzonych z niedorozwojem środkowego piętra twarzy sugerują leczenie chirurgiczne obejmujące wysunięcie kompleksu szczękowo jarzmowego, co poprawia drożność górnych dróg oddechowych. Wśród farmakoterapii wymieniane są leki: stymulujące oddychanie - medroksyprogesteron, psychotropowe, na przykład selektywne inhibitory wychwytu zwrotnego serotoniny, hipotensyjne $[5,8]$.

\section{Cel pracy}

Celem pracy jest dokonanie przeglądu polskiego piśmiennictwa dotyczącego diagnostyki i leczenia obturacyjnego bezdechu sennego w powiązaniu z ortodoncją.

\section{Materiał i metody}

Przeanalizowano 30 artykułów polskich autorów. Wykorzystano słowa kluczowe: obturacyjny bezdech senny, OBS, cefalometria. Do niniejszego opracowanie wybrano 4 prace z ostatniego pięciolecia.

\section{Wyniki}

Bezpośrednia przyczyna obturacyjnego bezdechu sennego nie jest do końca poznana, lecz istnieją udowodnione ogólne i miejscowe czynniki ryzyka. Wśród przyczyn ogólnoustrojowych wymienić należy przede wszystkim otyłość, spożywanie alkoholu, głównie przed snem, palenie papierosów, wiek. Nadmiar tkanki tłuszczowej w okolicy szyjnej zwiększającej obwód szyi u mężczyzn powyżej 43 $\mathrm{cm}$, a u kobiet $40 \mathrm{~cm}$ powoduje zmniejszenie drożności górnych dróg oddechowych, a zatem jest jedną z przyczyn OBS. U kobiet ryzyko pojawienia się OBS jest mniejsze $[9,10]$.

Na zdjęciu cefalometrycznym u osób cierpiących na OBS można zaobserwować nieprawidłowości, takie jak: zwiększenie długości podniebienia miękkiego, obniżenie kości gnykowej, cofnięcie szczęki oraz żuchwy. Oceny położenia kości gnykowej dokonuje się, mierząc odcinek S (Sella) do H (Hyoidale) - ciężką postać OBS możemy stwierdzić, gdy wartość ta przekracza $12 \mathrm{~cm}$. Natomiast długość podniebienia miękkiego sprawdza się, wyznaczając długość odcinka PNS (spina nasalis posterior) do U (Uvula - koniec języczka) - średnia dla kobiet wynosi $35 \mathrm{~mm}$, dla mężczyzn $34 \mathrm{~mm}$. Ze względu na wysoką korelację tomografii komputerowej i endoskopii $z$ dwuwymiarowym badaniem cefalometrycznym można je wykorzystać $w$ diagnostyce górnych dróg oddechowych [10, 11].

Zaburzenia snu spowodowane bezdechem sennym znacznie utrudniają codzienne życie. Chorzy uskarżają się na zmęczenie, zaburzenie funkcji poznawczych, utrudnione zapamiętywanie, są rozdrażnieni, czasem mogą występować stany depresyjne. Znacznie poważniejsze są powikłania związane z ogólnym stanem zdrowia. Nieleczony OBS prowadzi do zaburzeń sercowo-naczyniowych, zaburzeń rytmu serca, powstania nadciśnienia tętniczego, rozwoju blaszki miażdżycowej, cukrzycy, nadmiernego pobudzenia układu współczulnego. W przypadku OBS należy w miarę możliwości wyeliminować czynniki sprawcze. Często spotykana wśród pacjentów jest otyłość - w otyłości olbrzymiej wymagane jest zakwalifikowanie do operacji bariatrycznej. Przy braku skuteczności stosuje się leczenie ogólne, farmakologiczne lub leczenie miejscowe, zachowawcze i chirurgiczne. W leczeniu zachowawczym stosowana jest tlenoterapia, aparat CPAP powodujący wzrost ciśnienia w drogach oddechowych i aparaty wysuwające żuchwę i poprawiające położenie języka. Do innych metod operacyjnych należą: operacje nosa, przemieszczenie przyczepu mięśnia bródkowo-językowego, 
ablacja podstawy języka za pomocą fal radiowych, uwulopalatoplastyka z użyciem lasera, korekta położenia kości gnykowej, wysunięcie żuchwy, poszerzenie szczęki, adenotonsillektomia [9, 12].

\section{Podsumowanie}

W pracy przedstawiono niektóre problemy związane z etiologią, diagnostyką i sposobami leczenia pacjentów z OBS. Problem ten, dawniej niedoceniany, staje się coraz częściej domeną zainteresowania ortodontów, protetyków, laryngologów i chirurgów szczękowych. Szczególnie ortodonci mają możliwości zachowawczego leczenia OBS z efektem dużej skuteczności.

\section{Oświadczenia}

Oświadczenie dotyczące konfliktu interesów

Autorzy deklarują brak konfliktu interesów w autorstwie oraz publikacji pracy.

\section{Źródła finansowania}

Autorzy deklarują brak źródeł finansowania.

\section{Piśmiennictwo}

[1] Chruściel-Nogalska $M$, Kozak M, Ey-Chmielewska $H$. Zespół obturacyjnego bezdechu podczas snu podstawy diagnostyki i leczenia. Dental Forum. 2015;43;65-69.

[2] Kuźmińska M. Obturacyjny bezdech senny - czy jest problemem ludzi starszych? Postępy Nauk Medycznych. 2011;24;440-445.

[3] Szymańska J, Dobrowolska-Zarzycka M. Objawy, powikłania i leczenie obturacyjnego bezdechu sennego. Medycyna Ogólna i Nauki o Zdrowiu; 2013;19;391-396.

[4] Tomaszewska M, Kowalska-Kouassi D, Jackowska T, Zawadzka-Głos L, Kukwa W. Chrapiące dziecko - aktualne wytyczne dotyczące zasad rozpoznawania i leczenia obturacyjnego bezdechu sennego u dzieci. Postępy Nauk Medycznych. 2014;27;37-43.

[5] Przybyłowski T, Chazan R, Balcerzak J, Niemczyk K. Niezabiegowe leczenie Obturacyjnego Bezdechu Podczas Snu. Otorynolaryngologia. 2005;4;11-18.
[6] Wojda M, Kostrzewa-Janicka J. Obturacyjny bezdech senny - etiologia, rozpoznanie, leczenie. Protet. Stomatol. 2015;65;449-459.

[7] Chazan R, Przybyłowski T, Balcerzak J, Niemczyk K. Obturacyjny bezdech podczas snu - podstawy rozpoznawania. Otorynolaryngologia. 2004;3;133-139.

[8] Kiwilsza M, Staniszewska E, Miedzik M, Smektała T, Dowgierd K, Ciechanowski P, Sporniak-Tutak K. Niedorozwój środkowego piętra twarzy i jego kliniczne manifestacje w codziennej praktyce lekarza pediatry. Standardy Medyczne Pediatria. 2014;11;409-415.

[9] Tomaszewska-Jaźwiec A, Wiśniewska K, Wiśniewski M, Zawadzka-Głos L. Rola specjalistycznej współpracy lekarza laryngologa i ortodonty w wykrywaniu i zintegrowanym leczeniu pacjentów w wieku rozwojowym cierpiących na obturacyjny zespół snu z bezdechem, na podstawie przypadków własnych oraz piśmiennictwa. Nowa Pediatr. 2017;21;9-16.

[10] Matuszkiewicz A, Lasota A, Kiernicka K, Dunin-Wilczyńska I. Pacjent z obturacyjnym bezdechem sennym w gabinecie ortodontycznym - opis przypadku. Forum Ortod. 2018;14;309-320.

[11] Kołciuk L, Kołciuk A, Dylewski Ł, Zadurska M. Wpływ morfologii twarzowej części czaszki i stanu zgryzu na wymiar górnych dróg oddechowych - przegląd piśmiennictwa. Forum Ortod 2017;13;178-89.

[12] Matthews-Brzozowski A. Zespół obturacyjnego bezdechu sennego u dzieci z zespołem Downa. w: Fizykodiagnostyka i rehabilitacja w medycynie i stomatologii - zespół Downa. red. T. Matthews-Brzozowska, E. Mojs Wyd. Nauk. Uniw. Med. im. K. Marcinkowskiego w Poznaniu. Poznań. 2018;20-28.

Zaakceptowano do edycji: 2020-10-06 Zaakceptowano do publikacji: 2020-10-06

Adres do korespondencji:

Teresa Matthews-Brzozowska

Katedra i Klinika Ortopedii Szczękowej i Ortodoncji, Uniwersytet Medyczny im. Karola Marcinkowskiego w Poznaniu 